\title{
Association of multisite and site-specific fungicides in the control of Puccinia triticina and its effects on wheat yield
}

\author{
Deivid Sacon $^{1 *}$, Aline Netto ${ }^{2}$, Alessandra Gallina ${ }^{3}$, Eduardo Silvestrini Tonello ${ }^{4}$ and Paola Mendes Milanesi ${ }^{3}$ \\ ${ }^{1}$ Federal University of Viçosa. Viçosa, MG, Brazil. \\ ${ }^{2}$ ABC Farm Group, Sapezal, MT, Brazil. \\ ${ }^{3}$ Federal University of Fronteira Sul, Erechim, RS, Brazil. \\ ${ }^{4}$ Morgan Seeds and Biotechnology, Erechim, RS, Brazil. \\ *Author for correspondence: deividsacon@hotmail.com
}

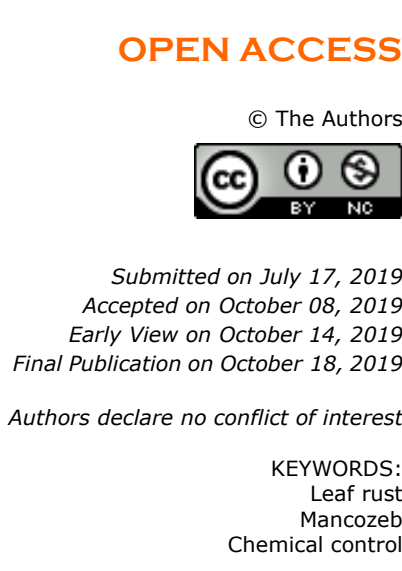

\section{ABSTRACT}

The wheat (Triticum aestivum L.) crop has great importance in the national context, the diseases are one of the main factors of losses, which emphasizes the importance of the pest system Triticum aestivum L. x Puccinia triticina Eriks. The aim of this study was to evaluate the efficiency of the combination of site-specific and multisite fungicides in the control of wheat leaf rust and its effects on crop yield. The evaluated treatments were: Control (absence of fungicide application); $\mathrm{T}+\mathrm{P}$ (trifloxystrobin + prothioconazole); $\mathrm{P}+\mathrm{F}$ (pyraclostrobin + fluxapyroxad); $\mathrm{T}+\mathrm{P}+\mathrm{Mb}$ (trifloxystrobin + prothioconazole + mancozeb); $\mathrm{P}+\mathrm{F}+\mathrm{Mb}$ (pyraclostrobin + fluxapyroxad + mancozeb) and Mb (mancozeb). Greater control of the disease was observed with the association of fungicides, there is a correlation between control and crop productivity, especially in harvest with greater severity of the disease.

Highlighted Conclusions

1. At low severity the wheat leaf rust does not present damage on crop productivity.

2. The association of multisite and site-specific fungicides increases the disease control effect.

3. The application fungicide program with the association of different a.i. maintains the crop yield potential.

4. The disease control has a positive effect on the yield components, on the other hand, the AUDPC presents a negative correlation.

\section{INTRODUCTION}

Since the 2 million hectares cultivated and the production of 5.4 million tons do not supply the country consumption, wheat (Triticum aestivum L.) has great economic importance for Brazil due to strong demand for its derivatives (Conab 2018). The diseases that occur in the crop during the whole cycle, and when under favorable conditions, can make the cultivation unfeasible (Draz et al. 2019).

Within the common wheat diseases, the most important is leaf rust, caused by the etiological agent Puccinia triticina Eriks. The symptoms are characterized by the presence of yellow-orange colored pustules, which are initially distributed on the adaxial side of the leaf. These pustules are succeeded by black oval-shaped telial pustules that remain on the leaf surface until the end of the crop cycle. Under ideal conditions for the pathogen development, wheat yield damage can reach up to $50 \%$ (Alves et al. 2018).

Among disease controlling tools, the use of resistant cultivars would be the most interesting, but this pathogen presents great plasticity in relation to the overcoming of specific resistance genes. Due to current virulence for most of the known Lr genes, chemical control is the main protagonist for the management of this disease (Alves et al. 2018).

In this sense, most of the fungicides in the current market act to inhibit the formation of fungal cell walls, that is, in the case of triazoles, or mitochondrial respiration, such as strobilurins and carboxamides (Arduim et al. 2012).

The appearance of insensitivity/resistance to fungicides is frequent in populations of pathogenic fungi. This effect is potentiated as the use of fungicides becomes generalized and followed by constant repetition of formulations with specific action active ingredients (a.i.). In some cases, the selection pressure may influence the appearance of insensitivity in a short time (Lucas et al. 2015). 
Grimmer et al. (2014) listed 61 cases of fungi resistant to site-specific fungicides recommended for wheat in Europe. In all cases, the time between the adoption of the product for field management and the appearance of the first reported resistance case ranged from two to twenty-four years.

In the search for the alternation of a.i. in order to reduce the selection pressure that may cause loss of efficiency of the fungicides in the control of Puccinia triticina, it is possible to associate fungicides based on mancozeb in the treatments. These products have potential for adoption among fungicides mixtures that aim at increase the control efficiency of pathogens. This is due to the fact that mancozeb is a multisite fungicide with broad action spectrum (Garcés-Fiallos and Forcelini 2013).

Fungicides with multisite action, affect phytopathogens in different ways, unlike those of specific site, such as triazoles, strobilurins, and carboxamides. In this sense, the multisites favor disease control and, consequently, reduce its severity and resistance risk, by protecting the yield potential of crops (Reis et al. 2016). The adoption of strategies to overcome the resistance of pathogens to fungicides is an important step for the maintenance of tools that are available in the market and that still act efficiently for wheat leaf rust management.

Therefore, due to the importance of the association of fungicides in the anti-resistance management of Puccina triticina, the aim of this work was to evaluate the efficiency of the association of site-specific and multisite fungicides in wheat leaf rust control and its effects on crop yield.

\section{MATERIAL AND METHODS}

The experiment was conducted in Erechim-RS ( $27^{\circ} 37^{\prime} 50^{\prime \prime} \mathrm{S}, 52^{\circ} 14^{\prime} 11^{\prime \prime} \mathrm{W}$, altitude: $\left.753 \mathrm{~m}\right)$ in the winter crops of 2016 and 2017. The soil of the site is characterized as a Humic Aluminoferric Red Latosol - Oxysol (Embrapa 2013) and, soil characteristics (depth $0-0.10 \mathrm{~m}$ ) were: clay: $75.9 \%$; sand: $7.0 \%$; silt $17.1 \%$; organic matter: $3.6 \%$; pH: 5.4; P: $5.7 \mathrm{mg} \mathrm{dm}^{-3}$; K: $89 \mathrm{cmolc} \mathrm{dm}^{-3}$; Al: $0.2 \mathrm{cmolc} \mathrm{dm}^{-3}$; Ca: $5.6 \mathrm{cmol}_{\mathrm{c}} \mathrm{dm}^{-3}$; $\mathrm{Mg}: 2.8 \mathrm{cmolc} \mathrm{dm}^{-3}$; e CTC: 14.2 $\mathrm{cmol}_{\mathrm{c}} \mathrm{dm}^{-3}$. The crop was sown on the soybean stand and, before sowing, the herbicides glyphosate $(1550 \mathrm{~g}$ a.i. $\left.\mathrm{ha}^{-1}\right)$ and 2,4-D (670 $\mathrm{g}$ a.i. ha- $\left.\mathrm{H}^{-1}\right)$ were applied for desiccation of the area 30 days prior to sowing. The wheat cultivar used for this experiment was TBIO Toruk, sowed at 06/10/2016 and 06/16/2017.

The fertilization in the furrow was made with mineral fertilizer NPK (05-20-20), in the proportion of $250 \mathrm{~kg} \mathrm{ha}^{-1}$. Coverage was applied with $150 \mathrm{~kg} \mathrm{ha}^{-1}$ of nitrogen in the form of urea, $40 \%$ at the beginning of tillering and $60 \%$ at the beginning of the rubbering (Silva et al. 2017).

The experimental design was a complete randomized complete block (CRB), with four replicates. Each plot had dimensions of $3.0 \mathrm{~m}$ wide by $6.0 \mathrm{~m}$ long, totaling $18.0 \mathrm{~m}^{2}$, with a useful area of $4.0 \mathrm{~m}^{2}$. The treatments used were: Control (absence of fungicide application); $\mathrm{T}+\mathrm{P}$ (trifloxystrobin + prothioconazole, $75+87.5 \mathrm{~g}$ a.i. ha-1); $\mathrm{P}+\mathrm{F}$ (pyraclostrobin + fluxapyroxad; $116.5+58.5 \mathrm{~g}$ a.i. ha- $\left.{ }^{-1}\right) ; \mathrm{T}+\mathrm{P}+\mathrm{Mb}$ (trifloxystrobin + prothioconazole + mancozeb; $75+87.5+1870 \mathrm{~g}$ a.i. ha- $\left.{ }^{-1}\right) ; \mathrm{P}+\mathrm{F}+\mathrm{Mb}$ (pyraclostrobin + fluxapyroxad + mancozeb; $116.5+58.5+1870 \mathrm{~g}$ a.i. $\mathrm{ha}^{-1}$ ) and $\mathrm{Mb}$ (mancozeb $+1870 \mathrm{~g}$ a.i. ha ${ }^{-1}$ ). The adjuvant dose followed the manufacturer's recommendation for each fungicide.

The determined fungicide treatments were applied with the aid of $\mathrm{C}_{2}$ pressurized sprayer, adjusted to obtain a constant flow of $150 \mathrm{~L} \mathrm{ha}^{-1}$ with a TXA $8002 \mathrm{VK}$ conical spray nozzle. Four applications of fungicides were carried out throughout the development of the crop, the first one being carried out in the tillering phase and, for subsequent applications, the 18-day interval between applications was respected.

Severity assessments began when the first symptoms were identified, for this, 10 leaves were evaluated weekly in each experimental unit. Evaluations were performed at seven-day intervals, comparing the symptomatic leaves using the Cobb diagram scale (Peterson et al. 1948). With the information obtained, the area under the disease progress curve (AUDPC) was determined following the equation proposed by Campbell and Madden (1990).

$A U D P C=\sum\left\{\left[\frac{Y_{i}+Y_{i+1}}{2}\right] x\left(t_{i=1}-t_{i}\right)\right\}$

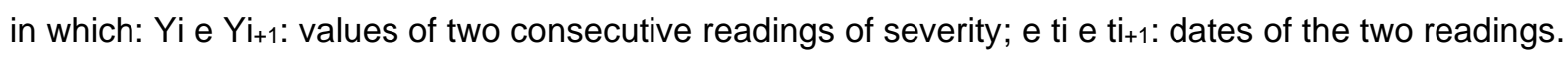

Harvesting was performed when the crop reached physiological maturity and, for this purpose, a $4.0 \mathrm{~m}^{2}$ area was demarcated in the center of the plot. Samples were harvested and threshed with the aid of plot stationary threshing to estimate the productivity $\left(\mathrm{kg} \mathrm{ha}^{-1}\right)$. Then, a grain sample of each plot was used for the determination of humidity by the oven at $105^{\circ} \mathrm{C}$ (Brasil 2009). In addition, the weight of one thousand grains (WTG, g) and the hectoliter weight $(\mathrm{HW})$ were also determined. Based on the humidity of each sample, the correction of productivity, HW and WTG to $13 \%$ was performed.

The data were submitted to normality analysis of residues (Shapiro-Wilk, $p \leq 0.05$ ) and homogeneity of variance (Neill and Mathews, $p \leq 0.05)$. Subsequently, the analysis of variance was performed using the $F$ test $(p \leq$ 
$0.05)$ and, when significant, Tukey's test $(p \leq 0.05)$ was used. For correlation analysis, the variables were analyzed using the Pearson test. The analyzes were performed using statistical software R (R Core Team 2017).

\section{RESULTS AND DISCUSSION}

In the 2016 harvest, no differentiation between treatments was observed when the productivity, HW and WTG of wheat were evaluated (Table 1). The lack of distinction between treatments can be attributed to the low intensity of the disease in relation to the next evaluation (harvest 2017). There was a correlation of 0.56 between crop yield and WTG, and 0.45 between yield and HW, which, in turn, also showed a significant correlation with WTG $(0.42)$ (Figure 1).

Table 1. Productivity $\left(\mathrm{kg} \mathrm{ha}^{-1}\right)$, hectoliter weight (HW), weight of thousand grains (WTG), area under the disease progress curve (AUDPC), and leaf rust control (\%) of wheat (cv. TBIO Toruk), in relation to the application of fungicides. Erechim, RS, 2016.

\begin{tabular}{|c|c|c|c|c|c|}
\hline Treatments* & $\begin{array}{l}\text { Productivity } \\
\left(\mathrm{kg} \mathrm{ha}^{-1}\right)\end{array}$ & HW & WTG (g) & AUDPC & $\begin{array}{c}\text { Control } \\
(\%)\end{array}$ \\
\hline Control & $4,366.1^{\text {ns }}$ & $78.9^{\text {ns }}$ & $35.9^{\text {ns }}$ & $128.1 b^{\star *}$ & $0.0 \mathrm{c}$ \\
\hline $\mathrm{T}+\mathrm{P}$ & $4,210.6$ & 77.3 & 37.0 & 33.7 a & $73.5 a b$ \\
\hline $\mathrm{P}+\mathrm{F}$ & $4,528.6$ & 79.0 & 38.6 & $37.8 \mathrm{a}$ & $71.0 \mathrm{ab}$ \\
\hline $\mathrm{T}+\mathrm{P}+\mathrm{Mb}$ & $4,772.5$ & 78.6 & 38.4 & $40.8 \mathrm{a}$ & $68.0 \mathrm{ab}$ \\
\hline $\mathrm{P}+\mathrm{F}+\mathrm{Mb}$ & $4,873.3$ & 79.0 & 39.6 & $32.6 \mathrm{a}$ & $74.5 \mathrm{a}$ \\
\hline $\mathrm{Mb}$ & $4,898.6$ & 79.6 & 40.0 & $55.0 \mathrm{a}$ & $56.9 \mathrm{~b}$ \\
\hline C.V. (\%) & 9.9 & 1.3 & 5.2 & 17.9 & 12.5 \\
\hline$p$-value & 0.23 & 0.09 & 0.12 & $1 \times 10^{-5}$ & $1 \times 10^{-5}$ \\
\hline
\end{tabular}

\section{PRODUCTIVITY}

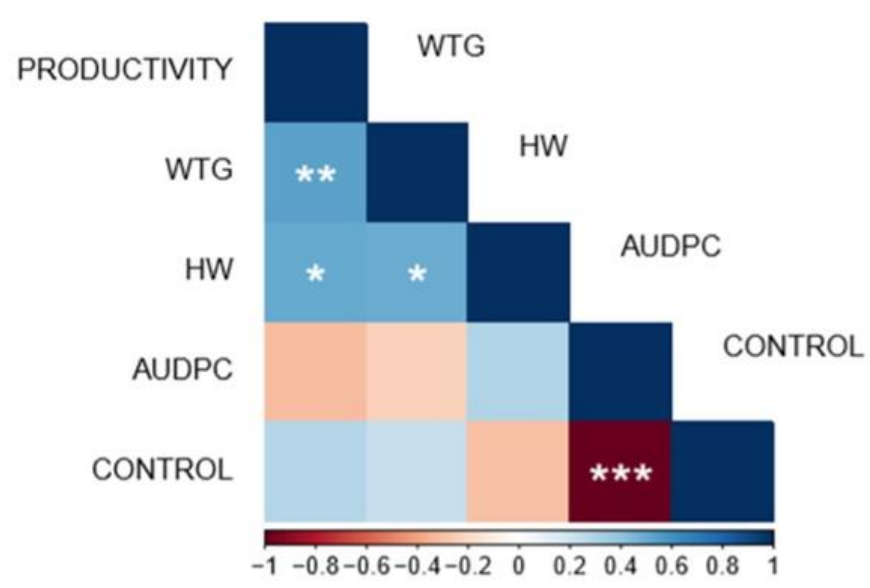

Figure 1. Pearson correlation coefficient between productivity $\left(\mathrm{kg} \mathrm{ha}^{-1}\right)$, weight of thousand grains (WTG, g), hectolitric weight (HW), AUDPC and Control (\%) of leaf rust of wheat (cv. TBIO Toruk), in relation to the application of fungicides. ${ }^{* * *}(p \leq 0.001) ;{ }^{* *}(p \leq$ $0.01)$; * ( $\leq$ 0.05); absence of *, it was not significant. Erechim, RS, 2016.

In relation to AUDPC, the highest values were observed in the plots without application of fungicides (128.1 units), while all the fungicides used decreased the severity of the disease (Table 1). The highest percentages of control were observed with the $\mathrm{P}+\mathrm{F}+\mathrm{Mb}(74.5 \%), \mathrm{T}+\mathrm{P}(73.5 \%), \mathrm{P}+\mathrm{F}(71.0 \%)$ and $\mathrm{T}+\mathrm{P}+\mathrm{Mb}(68.0 \%)$. The use of $\mathrm{Mb}$ (mancozeb) alone had a lower control percentage (56.9\%) compared to its use associated with site specific fungicide trifloxystrobin + prothioconazole.

In the 2017 harvest, under greater severity of the disease, there was an increase in the differentiation between treatments (Table 2). The highest values of productivity were observed in the treatments: $T+P+M b, 3,438.6 \mathrm{~kg}$ $\mathrm{ha}^{-1} ; \mathrm{P}+\mathrm{F}+\mathrm{Mb}, 2,992.6 \mathrm{~kg} \mathrm{ha}^{-1}$, and $\mathrm{T}+\mathrm{P}, 2,990.9 \mathrm{~kg} \mathrm{ha}^{-1}$. Followed by treatments: $\mathrm{P}+\mathrm{F}, 2,620.8 \mathrm{~kg} \mathrm{ha}^{-1} ; \mathrm{Mb}$, $2,581.7 \mathrm{~kg} \mathrm{ha}^{-1}$, and, Control, $2,435.4 \mathrm{~kg} \mathrm{ha}^{-1}$. There was no statistically significant difference between HW and WTG. 
Table 2. Productivity (kg ha-1), hectoliter weight (HW), weight of thousand grains (WTG), area under the disease progress curve (AUDPC), and leaf rust control (\%) of wheat (cv. TBIO Toruk), in relation to the application of fungicides. Erechim, RS, 2017.

\begin{tabular}{|c|c|c|c|c|c|}
\hline Treatments* & $\begin{array}{l}\text { Productivity } \\
\left(\mathrm{kg} \mathrm{ha}^{-1}\right)\end{array}$ & $\mathrm{HW}$ & WTG (g) & AUDPC & $\begin{array}{c}\text { Control } \\
(\%)\end{array}$ \\
\hline Control & $2,435.4 b^{\star \star}$ & $74.2^{\text {ns }}$ & $36.2^{\text {ns }}$ & $730.1 \mathrm{a}$ & $0.0 \mathrm{~d}$ \\
\hline $\mathrm{T}+\mathrm{P}$ & $2,990.9 \mathrm{ab}$ & 73.0 & 36.6 & $283.1 \mathrm{bc}$ & $61.2 \mathrm{abc}$ \\
\hline $\mathrm{P}+\mathrm{F}$ & $2,620.8 \mathrm{~b}$ & 75.8 & 37.3 & $311.8 \mathrm{bc}$ & 57.2 bc \\
\hline $\mathrm{T}+\mathrm{P}+\mathrm{Mb}$ & $3,438.6 \mathrm{a}$ & 75.6 & 38.1 & $154.0 \mathrm{c}$ & 78.9 a \\
\hline $\mathrm{P}+\mathrm{F}+\mathrm{Mb}$ & $2,992.6 a b$ & 74.6 & 37.6 & $176.8 \mathrm{bc}$ & $75.7 a b$ \\
\hline $\mathrm{Mb}$ & $2,581.7 \mathrm{~b}$ & 75.1 & 37.7 & $344.3 \mathrm{~b}$ & $52.8 \mathrm{c}$ \\
\hline C.V. (\%) & 11.7 & 2.4 & 3.5 & 24.1 & 15.1 \\
\hline$p$-value & 0.01 & 0.22 & 0.24 & $1 \times 10^{-5}$ & $1 \times 10^{-5}$ \\
\hline
\end{tabular}

\section{PRODUCTIVITY}

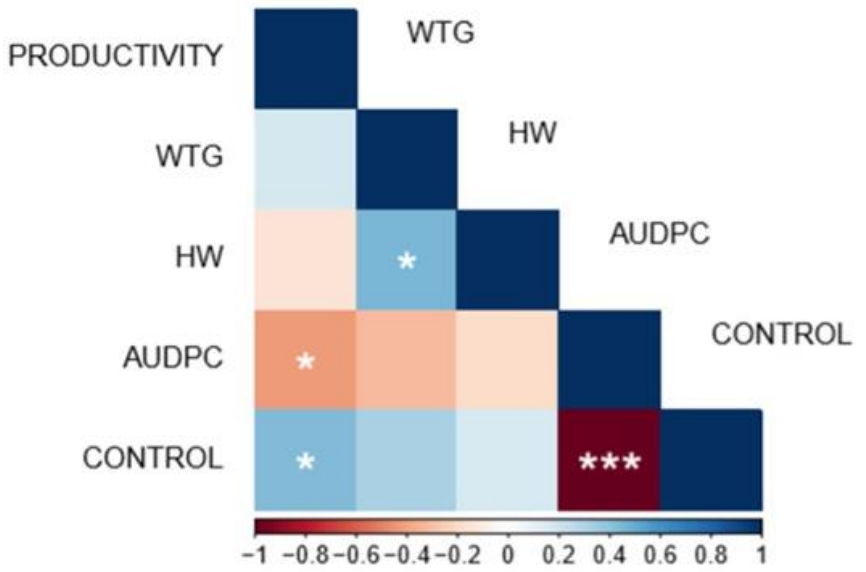

Figure 2. Pearson correlation coefficient between productivity $\left(\mathrm{kg} \mathrm{ha}^{-1}\right)$, weight of thousand grains (WTG, g), hectolitric weight (HW), AUDPC and Control (\%) of leaf rust of wheat (cv. TBIO Toruk), in relation to the application of fungicides. ${ }^{* *}(p \leq 0.001) ;{ }^{*}(p \leq$ 0.05); absence of ${ }^{*}$, it was not significant. Erechim, RS, 2017.

The correlation between disease control and crop productivity was significant $(0.46)$ in the 2017 harvest (Figure 2). Also, the highest correlation coefficients between AUDPC, control, and productivity were obtained in the 2017 harvest, which may have occurred due to the higher severity of the disease and interference with productivity. The control did not show any significant correlation for the other yield components (Figure 2).

The highest values of AUDPC were observed in the plots with no application of fungicide in the 2017 harvest, 730.1 units (Table 2), surpassing the previous year Control (2016) in 5.7 times (Table 1). The plots with application $\mathrm{T}+\mathrm{P}+\mathrm{Mb}, \mathrm{P}+\mathrm{F}+\mathrm{Mb}$ and $\mathrm{T}+\mathrm{P}$, treatments had the highest percentages of control, $78.9 \% ; 75.7 \%$; and $61.2 \%$, respectively. Already lower percentages of control were observed with the application of $P+F(57.7 \%)$ and $M b$ (52.8\%).

The association of a.i. aids in the broadening of the spectrum of fungicidal action, delaying the appearance of cases of insensitivity in the population of the pathogen. Kang et al. (2019), when evaluating the sensitivity of 39 isolates of Puccinia striiformis f. sp. tritici (Pst), observed differences in the behavior of the isolates when submitted to different concentrations of propiconazole $(0.0 \times, 0.01 \times, 0.02 \times, 0.04 \times, 0.08 \times, 0.10 \times, 0.15 \times, 0.20 \times$ and $1.0 \times)$ and pyraclostrobin $(0.0 \times, 0.00075 \times, 0.00100 \times, 0.00150 \times, 0.00200 \times, 0.00300 \times, 0.00400 \times, 0.00600 \times, 0.00750$ $\times$, and $1.0 \times$ ), thus confirming the first report of differences in Pst sensitivity to these fungicides in the United States. The sources of genetic resistance to Puccinia triticina constitute an important tool in disease management in the wheat production system, but when used alone, there is a tendency of this technology to be broken up to five years (Bhardwaj et al. 2019 ), reinforcing the importance of proper use of chemical control, delaying the occurrence of focus of insensitivity of the pathogen and maintaining the fungicides with high control efficiency in the market. 
Crop yield was only affected under more severe conditions of infection on the harvest 2017, but no significant difference was observed for HW and WTG (Table 2). These results are similar to those obtained by Oliveira et al. (2013), on what under conditions of high severity of Puccinia triticina (2,031.4 units of AUDPC in the absence of fungicide application), observed a direct relationship between the delay of fungicide applications and the reduction of crop yield, estimating a damage of $80.5 \mathrm{~kg} \mathrm{ha}^{-1}$ for each day of application delay after identification of the first symptoms. However, the authors did not identify significant differences in the WTG variable.

In contrast, Draz et al. (2019), testing inducers of resistance in wheat culture against Puccinia triticina infection, under field conditions, with artificial inoculation of the pathogen, observed increases in the WTG (g) yield component and also in the HW, when using the extract of lantana (Lantana camara) and diniconazole fungicide, being 31 and $27 \%$, respectively for WTG and 13 and $11 \%$, respectively, for HW.

Finally, the crop productivity correlated with the efficiency of the control of the disease and, in addition to contributing to the control efficiency of the disease, the multisite fungicides present a low risk of resistance, helping in the anti-resistance management of the pathogen.

\section{References}

Alves GCS et al. 2018. Escala diagramática para quantificação da ferrugem da folha do trigo. Multi-Science Journal 1:128-133.

Arduim GS et al. 2012. In vivo sensitivity reduction of Puccinia triticina races, causal agent of wheat leaf rust, to DMI and Qol fungicides. Summa Phytopathologica 34:306-311

Bhardwaj, SC et al. 2019. Physiologic specialization and shift in Puccinia triticina pathotypes on wheat in Indian subcontinent during 20132016. Indian Phytopathology 72:22-34

Brasil. 2009. Regras para análise de sementes. Brasília: Mapa/ACS.

Campbell CL and Madden LV. 1990. Introduction to plant disease epidemiology. New York: Wiley-Blackwell.

Conab - Companhia Nacional de Abastecimento. 2018. Acompanhamento da Safra Brasileira: grãos: $12^{\circ}$ levantamento: safra 2017/18.

Available in https://www.conab.gov.br/info-agro/safras/graos/boletim-da-safra-de-graos. Accessed on March 17, 2019.

Draz IS et al. 2019. Application of plant extracts as inducers to challenge leaf rust of wheat. Egyptian Journal of Biological Pest Control 29:1-8.

Embrapa - Empresa Brasileira de Pesquisa Agropecuária. 2013. Sistema brasileiro de classificação de solos. 3. ed. Brasília: Embrapa, pp.353.

Garcés-Fiallos FR and Forcelini CA. 2013. Controle comparativo da ferrugem asiática da soja com fungicida triazol ou mistura de triazol + estrobilurina. Bioscience Journal 29:805-815.

Grimmer MK et al. 2014. Fungicide resistance risk assessment based on traits associated with the rate of pathogen evolution. Pest Management Science 71:207-215.

Kang Z et al. 2019. Differential sensitivity among Puccinia striiformis f. sp. tritici isolates to propiconazole and pyraclostrobin fungicides. Canadian Journal of Plant Pathology 41:415-434.

Lucas JA et al. 2015. The evolution of fungicide resistance. Advances in Applied Microbiology, 90:29-92.

Oliveira GM et al. 2013. Controle da ferrugem da folha do trigo (Puccinia triticina) em diferentes momentos de aplicação de fungicida. Arquivos do Instituto Biológico 80:436-441.

Peterson F, Campbell B, Hannah E (1948). A diagrammatic scale for estimating rust intensity on leaves and stems of cereals. Canadian Journal of Research 26:496-500.

R Core Team. 2017. R: A language and environment for statistical computing. R Foundation for Statistical Computing, Vienna, Austria. Available in https://www.gbif.org/tool/81287/r-a-language-and-environment-for-statistical-computing. Accessed on Mar. 17, 2019.

Reis EM et al. 2016. Manual de fungicidas: guia para o controle químico racional de doenças de plantas. Passo Fundo: Berthier.

Silva SR et al. 2017. Informações técnicas para trigo e triticale - safra 2017. Passo Fundo: Embrapa. Available in https://www.embrapa.br/busca-de-publicacoes/-/publicacao/1064344/informacoes-tecnicas-para-trigo-e-triticale---safra-2017. Accessed on Mar. 17, 2019. 